\title{
FILOSOFI TRI KAYA PARISUDHA MEMODERASI PENGARUH EQUITY SENSITIVITY DAN ETHICAL SENSITIVITY PADA PERILAKU ETIS AUDITOR BADAN PEMERIKSA KEUANGAN PERWAKILAN PROVINSI BALI
}

\author{
Oleh \\ I Gusti Putu Eka Rustiana Dewi \\ Universitas Udayana \\ agungekard@gmail.com
}

diterima 14 Desember 2018, direvisi 10 Februari 2019, diterbitkan 28 Februari 2019

\begin{abstract}
This Study aims to examine the effect of equity sensitivity and ethical sensitivity on auditor's ethical behavior in Financial Audit Board of Republic Indonesia (BPK RI) Representatives of Bali Province, as well as to examine whether philosophy of tri kaya parisudha which is one of local wisdom found in Bali will be able to strengthen the effect of equity sensitivity and ethical sensitivity on auditor's ethical behavior. The research conducted because of the phenomenon of bribery cases which were involving auditors of BPK and have added to the list of corruption cases in Indonesia. Data collection in the research using survey method with questionnaire and the sample are 45 auditors of BPK RI representatives of Bali Province. The result shows that equity sensitivity and ethical sensitivity have positive significant effect on auditor's ethical behavior, while the philosophy of tri kaya parisudha has an ability to strengthen the effect of equity sensitivity and ethical sensitivity on auditor's ethical behavior.
\end{abstract}

\section{Keywords : Ethical Behavior, Equity Sensitivity, Ethical Sensitivity, Filosofi} Tri kaya parisudha

\section{PENDAHULUAN}

Masalah etika yang banyak terjadi belakangan ini terkait dengan auditing, perlu mendapat perhatian khusus akan pentingnya nilai - nilai etika. Banyak auditor harus menghadapi masalah serius karena tidak mengindahkan adanya nilai-nilai etika dan melakukan kesalahan serta pelanggaran terhadap kode etik dan profesi. Oleh sebab itu, penting bagi seorang auditor memiliki pengetahuan terhadap tanda-tanda peringatan munculnya masalah etika guna memberikan peluang untuk melindungi diri sendiri, dan pada saat yang sama akan membangun suasana etis di dalam lingkungan kerjanya. 
Masalah-masalah etika yang dapat dihadapi oleh auditor di antaranya adalah auditor dalam melaksanakan tugas mengkompromikan integritasnya dengan melakukan pemalsuan, penggelapan atau penyuapan, dan mendistorsi obyektifitas dengan menerbitkan laporan-laporan yang menyesatkan. Semua permasalahan tersebut merupakan pelanggaran yang serius terhadap prinsip dasar dan kode etik yang menjadi standar dan aturan etika profesi audit, dimana kode etik atau aturan etika profesi audit menyediakan panduan bagi para auditor profesional untuk mempertahankan diri menghadapi godaan saat berada dalam dilema atau pertimbangan dan pengambilan keputusan yang sulit.

Dilema etika dalam auditing tidak hanya dialami oleh auditor independen atau akuntan publik, tetapi juga auditor pemerintah khususnya auditor eksternal pemerintah yang dilaksanakan oleh Badan Pemeriksa Keuangan di Indonesia. Dalam pasal 23 ayat 5 UUD tahun 1945 menetapkan BPK adalah lembaga tinggi negara yang bebas dan mandiri yang bertugas memeriksa tanggung jawab keuangan negara, hasil pemeriksaan tersebut akan disampaikan kepada Dewan Perwakilan Rakyat. Pemeriksaan pengelolaan dan tanggung jawab BPK terbatas pada pemerintah pusat, pemerintah daerah, Bank Indonesia, BUMN, Badan Layanan Umum, BUMD, dan semua lembaga yang mengelola keuangan negara. Munculnya fenomena kasus praktik suap yang melibatkan auditor BPK terjadi di tahun 2017 menambah panjang daftar kasus korupsi yang terjadi di Indonesia. Dua kasus yang ditemukan oleh KPK (Komisi Pemberantasan Korupsi) di tahun 2017 adalah kasus suap motor Harley Davidson oleh pejabat BUMN PT Jasa Marga (persero) berkenaan dengan temuan penyelewengan laporan keuangan dan kasus suap sebesar 240 juta rupiah oleh mantan pejabat Kementerian Desa, Pembangunan Daerah Tertinggal, dan Transmigrasi berkenaan dengan usaha mendapatkan opini wajar tanpa pengecualian. Data dari Indonesian Corruption Watch mencatat sedikitnya ada enam kasus suap yang melibatkan 23 orang auditor BPK dalam 12 tahun terakhir.

Penerimaan suap yang dilakukan BPK merupakan tindakan korupsi yang melanggar kepercayaan publik dan prinsip etika yaitu kejujuran, keadilan, obyektifitas, serta legalitas. Dewi (2015) menyatakan bahwa kegagalan atau penyimpangan audit yang dilakukan oleh auditor mendorong diperlukannya kemampuan internal auditor untuk mempertimbangkan etika dan perilaku dalam pelaksanaan audit. Huseman (1987) menyatakan bahwa equity sensitivity adalah salah satu faktor internal yang dapat mempengaruhi perilaku etis seseorang, equity sensitivity didefinisikan sebagai variabel personalitas yang menunjukkan reaksi individu ketika merasakan adil dan tidak adil. Susanti (2014) mendefinisikan equity sensitivity sebagai persepsi individu yang menggambarkan keseimbangan antara input dan outcomes, sehingga berada di tengah-tengah antara benevolent dan entitleds. Pada titik keseimbangan ini, individu memiliki sifat yang tidak suka menuntut haknya serta memiliki tanggung jawab besar terhadap apa yang dikerjakan serta tidak membandingkan apa yang ia terima dengan apa yang diperoleh orang lain.

Faktor internal lain yang dapat mempengaruhi perilaku individu adalah ethical sensitivity. Menurut Fahrianta dan Syam (2011), sensitivitas etika mengacu pada kemampuan seseorang mengidentifikasi konten etis dari suatu situasi tertentu. Kesadaran individu terhadap nilai moral dan etika akan sangat membantu auditor dalam menjalankan tugasnya secara professional. Susanti (2014) menyatakan sensitivitas etika adalah kesadaran individu bahwa mereka sebagai agen moral yang menyadari adanya nilai-nilai etika atau moral dalam suatu keputusan. Perilaku etis individu yang dipengaruhi oleh nilai moral dan etika tidak terlepas dari pengaruh agama dan budaya. Etika dan agama memiliki tujuan yang sama untuk meletakkan dasar ajaran moral agar individu dapat membedakan mana perbuatan yang baik dan buruk sehingga ajaran moral dalam agama dan budaya ini diharapkan 
dapat memperkuat nilai individu. Tri kaya parisudha adalah bagian dari filosofi dan ajaran etika agama Hindu, Sura (2001:95) menyatakan tri kaya parisudha terdiri dari tiga kata yang memiliki makna tri berarti tiga, kaya berarti anggota badan dan parisudha berarti suci, sehingga tri kaya parisudha memiliki makna tiga anggota badan yang disucikan meliputi manacika parisudha berarti berpikir yang baik, wacika parisudha berarti berkata-kata yang baik dan kayika parisudha berarti berbuat yang baik.

Sura (2001:94) menjelaskan bahwa segala yang dapat dilakukan manusia dapat berlangsung melalui tri kaya yaitu tiga anggota badan meliputi kaya, wak dan manah. Kaya bermakna anggota badan meliputi tangan, kaki, punggung dan sebagainya, wak bermakna kata-kata sedangkan manah bermakna pikiran. Dengan tiga alat ini manusia dapat berbuat sesuatu, baik terhadap dirinya sendiri maupun lingkungannya. Individu harus mampu memadukan pikiran, perkataan dan perbuatan baik dengan tetap menjaga hubungan harmonis antara sesama manusia, lingkungan dan Tuhan, sehingga dapat menjaga keseimbangan di dalam memberdayakan diri untuk mencapai kesadaran sejati (Suardikha, 2015). Jika dikaitkan dengan tugas seorang auditor, maka auditor diharapkan dapat menggunakan kesadarannya mengutamakan kode etik profesi, nilai moral dan etika, serta standar pedoman profesi dalam menjalankan tugas.

Beberapa penelitian terdahulu terkait hal ini dilakukan oleh Alleyne, et al (2013) yang meneliti pengaruh personal value terhadap perilaku etis 231 orang mahasiswa akuntansi dan non akuntansi universitas Karibia. Hasil penelitiannya menemukan bahwa faktor-faktor nilai individu mempengaruhi perilaku etis mahasiswa. Alteer, et al (2013) juga meneliti pengaruh religiusitas dan ethical sensitivity terhadap pertimbangan etis auditor, dengan hasil temuan religiusitas auditor dan ethical sensitivity berpengaruh positif terhadap pertimbangan etis auditor. Kusuma dan Budisantoso (2017) meneliti pengaruh equity sensitivity dan ethical sensitivity pada perilaku etis auditor kantor akuntan publik di Surabaya, hasil penelitiannya menunjukkan equity sensitivity dan ethical sensitivity berpengaruh positif terhadap perilaku etis auditor. Sedangkan penelitian Susanti (2014) menemukan hasil yang berbeda pada variabel equity sensitivity, dimana equity sensitivity tidak berpengaruh signifikan terhadap perilaku etis auditor kantor akuntan publik di wilayah Padang dan Pekanbaru. Penelitian Kunti (2012) menemukan bahwa terdapat perbedaan sensitivitas etika jika didasarkan atas gender, dimana hasil penelitiannya menunjukkan perempuan memiliki sensitivitas etika lebih baik daripada laki-laki sehingga perempuan cenderung berperilaku etis dibandingkan laki-laki.

Pada penelitian ini menggunakan variabel tri kaya parisudha yang merupakan filosofi Hindu Bali sebagai variabel moderasi dimana dalam konsep tri kaya parisudha terdapat ajaran nilai-nilai moral dan etika yang diharapkan mampu memperkuat nilai individu untuk berperilaku etis. Filosofi tri kaya parisudha memang hanya dikenal oleh masyarakat Hindu Bali namun ajaran kebenaran untuk berpikir, berkata dan berbuat baik merupakan nilai moral dan etika yang diajarkan oleh setiap agama untuk menuntun manusia dalam berperilaku. Masalah dan tujuan dalam penelitian ini adalah untuk menguji bagaimanakah pengaruh equity sensitivity dan ethical sensitivity pada perilaku etis auditor dan juga untuk menguji apakah filosofi tri kaya parisudha yang merupakan salah satu variabel local genus Hindu Bali mampu memperkuat pengaruh equity sensitivity dan ethical sensitivity pada perilaku etis auditor Badan Pemeriksa Keuangan Perwakilan Provinsi Bali.

\section{KAJIAN PUSTAKA}

Teori atribusi yang dikemukakan oleh Fritz Heider merupakan teori yang menjelaskan tentang perilaku seseorang. Dalam teori atribusi dijelaskan mengenai proses yang dapat menentukan penyebab dan 
motif perilaku seseorang. Luthans (2005) menjelaskan bahwa ada dua penyebab perilaku individu yaitu Dispotional attribution dan situational attribution. Dispotional attribution atau penyebab internal mengacu pada aspek perilaku individual yang ada pada diri seseorang seperti kepribadian, persepsi, kemampuan dan motivasi. Sedangkan situational attribution atau penyebab eksternal mengacu pada lingkungan sekitar yang dapat mempengaruhi perilaku seseorang seperti kondisi sosial, nilai-nilai sosial, dan pandangan masyarakat. Harold Kelley dalam Luthans (2005) menegaskan bahwa teori atribusi berhubungan dengan proses kognitif dimana individu menginterpretasikan perilaku berhubungan dengan bagian tertentu dari lingkungan yang relevan.

Pojman (1989) menjelaskan teori etika sebagai usaha sistematis untuk mengerti arti konsep moral yaitu konsep yang dapat menjelaskan suatu perbedaan antara yang benar dan salah, baik dan buruk, serta adil dan tidak adil. Hilmarsen (2011) menyebutkan bahwa perbedaan antara etika dan moral sangat jelas dalam filsafat, dimana etika dipandang sebagai teori dan moralitas sebagai praktiknya. Teori etika dapat dijadikan sebagai pedoman bagi auditor sebagai individu dalam bertindak menjalankan profesinya. Selanjutnya Kohlberg (1981) dalam teori perkembangan moral menyatakan bahwa penalaran moral adalah suatu pemikiran tentang masalah moral. Pemikiran itu merupakan prinsip yang dipakai dalam menilai dan melakukan suatu tindakan dalam situasi moral. Kohlberg menyebutkan bahwa penalaran moral dipandang sebagi suatu struktur bukan isi. Jika penalaran moral dipandang sebagai isi, maka sesuatu dikatakan baik atau buruk akan sangat tergantung pada lingkungan sosial budaya tertentu, sehingga sifatnya akan sangat relatif. Tetapi jika penalaran moral dilihat sebagai struktur, maka apa yang baik dan buruk terkait dengan prinsip filosofis moralitas, sehingga penalaran menjadi bersifat universal.
Equity sensitivity adalah persepsi seseorang terhadap keadilan dengan membandingkan input dan outcome yang diperoleh dari orang lain (Kusuma dan Budisantoso, 2017). Teori equity menurut Adams (1963) berfokus pada rasio inputoutput dalam organisasi. Input diwakili oleh kontribusi kita terhadap organisasi sedangkan output adalah segala sesuatu yang kita terima dari organisasi. Huseman (1987) menyatakan bahwa setiap individu memiliki persepsi tersendiri terhadap adil dan tidak adil. Huseman, et al (1987) membagi persepsi individu terhadap equity dan inequity dalam tiga kategori yaitu:

1) Benevolents: Individu benevolents cenderung berperilaku murah hati dan lebih senang memberi daripada menerima serta cenderung melakukan tindakan etis karena sifatnya yang tidak mementingkan diri sendiri. Individu benevolents akan merasa puas bila rasio outcome atau input mereka lebih rendah dibandingkan orang lain.

2) Equity sensitivity: Individu ini menganut norma equity dan merasa puas ketika rasio outcome atau input mereka sama dengan orang lain. Individu ini digambarkan memiliki keseimbangan antara input dan outcomes.

3) Entitleds: Individu ini digambarkan lebih senang menerima daripada memberi. Mereka tidak puas ketika rasio outcome atau input mereka lebih rendah dari orang lain. Individu ini lebih banyak menuntut haknya daripada memberi, sehingga individu ini cenderung melakukan perilaku tidak etis.

Ethical sensitivity adalah kemampuan untuk menyadari adanya nilai-nilai etika dalam suatu keputusan (Shaub, et al, 1993). Rest (1986) menyatakan bahwa individu dapat terlibat dalam perilaku tidak etis jika mereka gagal untuk mengenali kehadiran nilai-nilai etika. Hunt dan Vitel (1986) menjelaskan bahwa kemampuan seseorang 
untuk memahami masalah etis dipengaruhi oleh lingkungan budaya, lingkungan industri, lingkungan organisasi dan pengalaman pribadi. The Ethics Education Framework yang dipresentasikan oleh Dewan Standar Pendidikan Akuntansi International dalam Alteer, et al (2013) menggambarkan sensitivitas etika sebagai kemampuan individu untuk mengenali ancaman etika dan menyadari tindakan alternatif yang dapat memecahkan masalah etika. Saat individu berhadapan dengan dilema etika, persepsi individu dievaluasi dalam nilai etika atau penilaian moral untuk membuat keputusan. Individu harus memahami terlebih dahulu masalah etika untuk mengevaluasi situasi. Roxas dan Stoneback (1997) menyatakan bahwa penilaian etika berasal dari pertimbangan nilai moral yang membimbing perilaku.

Tri kaya parisudha merupakan salah satu falsafah kultur Hindu Bali yang mengajarkan setiap manusia senantiasa berbuat baik menjalankan kebenaran, memiliki etika dan budi pekerti luhur melalui pembinaan sikap. Sudharta dan Atmaja (2001:53) mendefinisikan tri kaya parisudha sebagai tiga dasar perilaku manusia yang harus disucikan yaitu berpikir baik, berkata baik dan berbuat baik. Filosofi tri kaya parisudha terdapat dalam kitab Sarasamuccaya yang memuat ajaran-ajaran etika yang menyajikan perintah dan larangan individu sebagai tuntunan berperilaku. Dalam kitab Sarasamuccaya disebutkan tri kaya parisudha terdiri atas:

1) Manacika parisudha: berarti pikiran yang baik atau suci, dalam Sarasamuccaya sloka 74 disebutkan ada tiga banyak gerak pikiran yang harus disucikan yaitu tidak ingin dan dengki terhadap milik orang lain, kasih sayang terhadap semua mahluk dan percaya dengan adanya karmaphala atau hasil dari perbuatan.

2) Wacika parisudha: berarti perkataan yang baik atau suci, dalam Sarasamuccaya sloka 75 disebutkan ada empat banyak perkataan yang harus dihindari yaitu perkataan jahat, perkataan kasar, perkataan memfitnah dan perkataan bohong atau tidak dapat dipercaya.

3) Kayika parisudha: berarti perbuatan yang baik atau suci, dalam Sarasamuccaya sloka 76 disebutkan ada tiga banyaknya perbuatan yang harus dihindari yaitu membunuh, mencuri dan berbuat zina.

Tri kaya parisudha merupakan satu kesatuan yang tidak dapat dipisahkan yang akan memberikan tuntunan individu dalam berperilaku. Pada dasarnya perkataan dan perbuatan bersumber atau berawal dari pikiran, kemudian pikiran yang baik akan menuntun manusia untuk berkata dan berbuat baik pula. Hal ini berarti yang paling awal yang harus dikendalikan individu adalah pikirannya. Segala hal yang mempengaruhi pikiran harus selalu terjaga seperti kestabilan jiwa. Dengan jiwa yang tenang, individu akan dapat mengendalikan pikirannya sehingga dapat berpikir baik yang pada akhirnya akan tercermin pada perkataan yang baik dan perbuatan yang baik.

Tabel 1 menunjukkan beberapa penelitian sebelumnya yang dilakukan baik itu penelitian asing maupun penelitian lokal yang digunakan sebagai kajian empiris dalam penelitian ini. Berikut daftar penelitian terdahulu disajikan di bawah ini:

Tabel 1 Penelitian Terdahulu

\begin{tabular}{|l|l|l|l|l|}
\hline No & $\begin{array}{c}\text { Author Name } \\
\text { (Year) }\end{array}$ & \multicolumn{1}{|c|}{ Title } & \multicolumn{1}{|c|}{ Variable } & \multicolumn{1}{c|}{ Conclusion } \\
\hline 1. & $\begin{array}{l}\text { Alteer, et al } \\
(2013)\end{array}$ & $\begin{array}{l}\text { Religiosity and } \\
\text { Auditor's Ethical }\end{array}$ & $\begin{array}{l}\text { Religiosity, } \\
\text { ethical }\end{array}$ & $\begin{array}{l}\text { Religiosity and ethical } \\
\text { sensitivity have }\end{array}$ \\
\hline
\end{tabular}




\begin{tabular}{|c|c|c|c|c|}
\hline & & $\begin{array}{l}\text { Sensitivity at Different } \\
\text { Levels of Ethical } \\
\text { Climate: A conceptual } \\
\text { link }\end{array}$ & $\begin{array}{l}\text { sensitivity, } \\
\text { ethical climate, } \\
\text { auditor's } \\
\text { ethical } \\
\text { judgement }\end{array}$ & $\begin{array}{l}\text { positive effect on } \\
\text { auditor's ethical } \\
\text { judgement, and ethical } \\
\text { climate have an ability } \\
\text { to moderate the effect } \\
\text { of religiosity on } \\
\text { ethical sensitivity }\end{array}$ \\
\hline 2. & $\begin{array}{l}\text { Alleyne, et al } \\
\text { (2013) }\end{array}$ & $\begin{array}{l}\text { Examining Personal } \\
\text { Value and Ethical } \\
\text { Behavior Perceptions } \\
\text { between Accounting } \\
\text { and Non Accounting } \\
\text { Students in Carribean }\end{array}$ & $\begin{array}{l}\text { Personal } \\
\text { value, ethical } \\
\text { behavior } \\
\text { perceptions }\end{array}$ & $\begin{array}{l}\text { Factors of personal } \\
\text { value have an effect } \\
\text { on ethical behavior } \\
\text { perceptions } \\
\text { accounting students }\end{array}$ \\
\hline 3. & $\begin{array}{l}\text { Kusuma dan } \\
\text { Budisantoso } \\
\text { (2017) }\end{array}$ & $\begin{array}{l}\text { Analysis The Effect of } \\
\text { Equity Sensitivity and } \\
\text { Ethical Sensitivity on } \\
\text { Auditor's Ethical } \\
\text { Behavior }\end{array}$ & $\begin{array}{l}\text { Equity } \\
\text { Sensitivity, } \\
\text { Ethical } \\
\text { Sensitivity, } \\
\text { Ethical } \\
\text { Behavior }\end{array}$ & $\begin{array}{l}\text { Equity sensitivity and } \\
\text { ethical sensitivity have } \\
\text { positive effect on } \\
\text { auditor's ethical } \\
\text { behavior }\end{array}$ \\
\hline 4. & $\begin{array}{l}\text { Susanti } \\
(2014)\end{array}$ & $\begin{array}{l}\text { The effect of Locus of } \\
\text { Control, Equity } \\
\text { Sensitivity, Ethical } \\
\text { Sensitivity and Gender } \\
\text { on Accountant's Ethical } \\
\text { Behavior }\end{array}$ & $\begin{array}{l}\text { Locus of } \\
\text { Control, } \\
\text { Equity } \\
\text { Sensitivity, } \\
\text { Ethical } \\
\text { Sensitivity, } \\
\text { Ethical } \\
\text { Behavior }\end{array}$ & $\begin{array}{l}\text { Locus of control and } \\
\text { ethical sensitivity have } \\
\text { positive effect on } \\
\text { accountant's ethical } \\
\text { behavior, and equity } \\
\text { sensitivity has } \\
\text { negative effect on } \\
\text { accountant's ethical } \\
\text { behavior }\end{array}$ \\
\hline 5. & $\begin{array}{l}\text { Fauzan } \\
\text { (2016) }\end{array}$ & $\begin{array}{l}\text { The effect of Religiosity } \\
\text { and ethical climate on } \\
\text { ethical behaviour }\end{array}$ & $\begin{array}{l}\text { Religiosity, } \\
\text { ethical climate, } \\
\text { ethical } \\
\text { behavior }\end{array}$ & $\begin{array}{l}\text { Religiosity and ethical } \\
\text { climate have positive } \\
\text { significant effect on } \\
\text { ethical behavior of } \\
\text { students of University } \\
\text { Utara Malaysia }\end{array}$ \\
\hline
\end{tabular}

Berdasarkan latar belakang, kajian teori dan penelitian terdahulu dari penelitian ini, maka dikembangkan kerangka berpikir dari penelitian sebagai berikut:

Filosofi Tri Kaya Parisudha Memoderasi Pengaruh Equity Sensitivity dan Ethical Sensitivity pada Perilaku Etis Auditor Badan Pemeriksa Keuangan Perwakilan Provinsi Bali

Kajian Teoritis

Kajian Empiris 


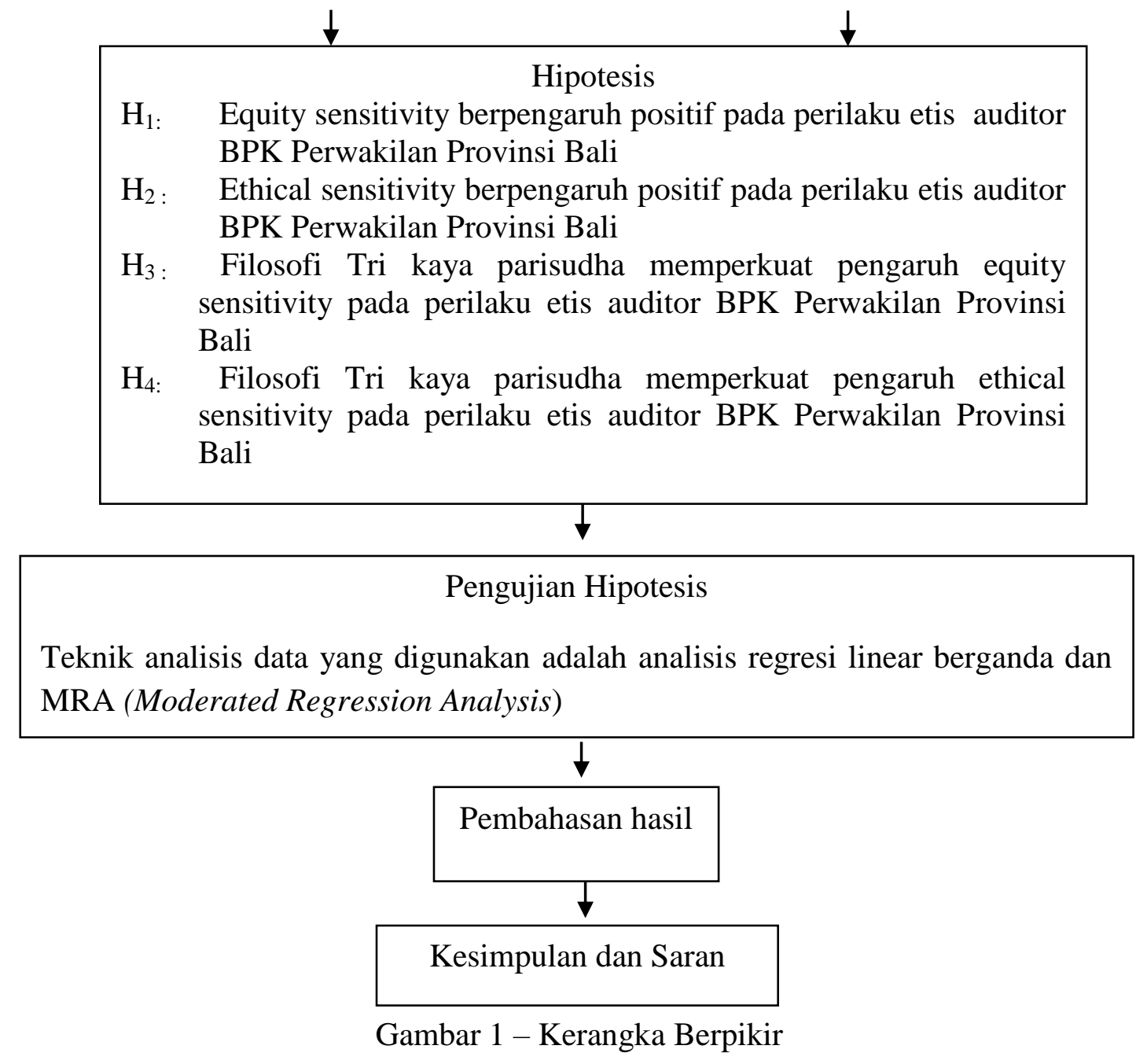

Adapun konsep penelitian ditunjukkan pada gambar di bawah ini:

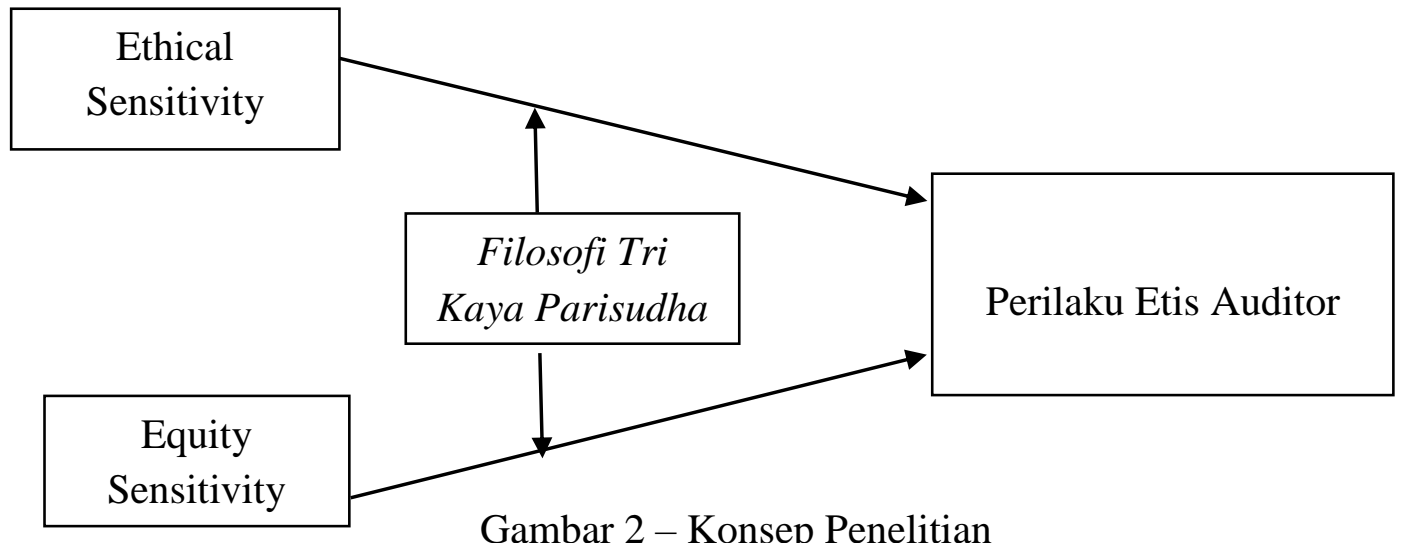

\section{METODE}

Pengumpulan data dalam penelitian menggunakan metode survei dengan kuesioner. Kuesioner yang telah disiapkan dikirimkan secara langsung kepada responden, sedangkan kuesioner yang digunakan adalah kuesioner yang kembali dan telah diisi secara lengkap oleh responden. Populasi dalam penelitian adalah auditor eksternal pemerintah Indonesia yang merupakan pegawai Badan Pemeriksa Keuangan Perwakilan Provinsi Bali berjumlah 45 orang. Metode pengambilan sampel yang digunakan adalah teknik 
sampling jenuh. Seluruh auditor yang bekerja dan bertugas melakukan pemeriksaan pada BPK Perwakilan Provinsi Bali pada tahun 2018 dijadikan sebagai sampel.

Variabel dependen dalam penelitian adalah perilaku etis auditor, variabel independen adalah equity sensitivity dan ethical sensitivity, dan filosofi tri kaya parisudha sebagai variabel moderasi. Instrumen yang digunakan untuk mengukur perilaku etis auditor adalah instrumen yang diadopsi dari Sihwahjoeni dan Gudono (2000), equity sensitivity diukur dengan menggunakan EPQ (Equity Preference Questionnaire) yang dikembangkan oleh Sauley dan Bedeian (2000), pengukuran ethical sensitivity dengan menggunakan instrumen yang diadopsi dari penelitian Shaub (1993), dan filosofi tri kaya parisudha diukur dengan menggunakan instrumen nilai individu yang diadopsi dari Akaah dan Lund (1994) dan Scott (1965).

Teknik analisis data yang digunakan dalam penelitian ini analisis regresi linear berganda dan MRA (Moderated Regression
Analysis). Teknik analisis data dalam penelitian diawali dengan pilot test dengan pengujian instrumen yaitu uji validitas dan uji reliabilitas. Uji asumsi klasik juga dilakukan untuk mengetahui bahwa model regresi yang digunakan bebas dari asumsi klasik. Pada penelitian ini, uji asumsi klasik yang digunakan adalah normalitas, multikolinearitas, dan heteroskedastisitas.

\section{HASIL DAN PEMBAHASAN}

Dari 45 kuesioner yang disebar pada auditor BPK, terdapat 5 kuesioner yang tidak kembali sehingga kuesioner yang digunakan dalam penelitian berjumlah 40 dengan tingkat pengembalian responden sebesar 88,88 persen. SPSS (Statistical Package for the Social Sciences) digunakan selanjutnya dalam analisis data pada statistik deskriptif, uji instrumen, uji asumsi klasik, analisis regresi linear berganda dan MRA (Moderated Regression Analysis). Statistik deskriptif yang memberikan informasi nilai minimum, nilai maksimum, nilai rata-rata, dan standar deviasi disajikan sebagai berikut:

Tabel 1 - Statistik Deskriptif

\begin{tabular}{|l|r|r|r|r|}
\hline \multicolumn{1}{|c|}{ Variabel } & Minimum & Maksimum & \multicolumn{1}{|c|}{$\begin{array}{c}\text { Rata-Rata } \\
\text { (Mean) }\end{array}$} & \multicolumn{1}{|c|}{$\begin{array}{c}\text { Standar } \\
\text { Deviasi }\end{array}$} \\
\hline Equity Sensitivity $\left(\mathrm{X}_{1}\right)$ & 12,97 & 45,24 & 31,5825 & 10,54527 \\
\hline Ethical Sensitivity $\left(\mathrm{X}_{2}\right)$ & 4,00 & 14,55 & 10,5207 & 3,61042 \\
\hline Tri kaya parisudha $\left(\mathrm{X}_{3}\right)$ & 19,07 & 60,21 & 44,6043 & 14,09680 \\
\hline Perilaku Etis Auditor $(\mathrm{Y})$ & 11,00 & 41,85 & 28,9123 & 9,84402 \\
\hline
\end{tabular}

Source: data analysis by using SPSS (2018)

Berdasarkan hasil statistik deskriptif pada Tabel 1, equity sensitivity dari auditor BPK Perwakilan Provinsi Bali masuk ke dalam kelompok cukup tinggi (25,87 $32,32)$, ethical sensitivity auditor masuk ke dalam kelompok tinggi $(10,33$ - 12,44), penerapan tri kaya parisudha auditor masuk ke dalam kelompok tinggi $(43,75$ - 51,98), dan perilaku etis auditor dalam menjalankan tugasnya masuk ke dalam kelompok cukup tinggi $(23,34$ - 29,51). Pada uji instrumen, hasil uji validitas nilai koefisien korelasi dari tiap item pertanyaan variabel equity sensitivity, ethical sensitivity, tri kaya parisudha, dan perilaku etis besarnya di atas 0,30 . Sehingga dapat dinyatakan bahwa seluruh pertanyaan dalam kuesioner tersebut valid dan layak digunakan dalam penelitian. Hasil uji reliabilitas menunjukkan nilai cronbach's alpha untuk variabel equity 
sensitivity, ethical sensitivity, tri kaya parisudha dan perilaku etis berturut-turut 0,966, 0,909, 0,973, dan 0,963 lebih besar dari 0,70 yang berarti bahwa seluruh instrumen reliabel.

Hasil uji asumsi klasik yaitu uji normalitas, uji multikolinearitas, dan uji heteroskedastisitas pada persamaan analisis regresi linear berganda dan persamaan analisis MRA menunjukkan bahwa kedua model persamaan bebas dari asumsi klasik. Hasil uji normalitas, multikolinearitas dan heteroskedastisitas disajikan pada tabel berikut:

Tabel 2 - Uji Normalitas

\begin{tabular}{|c|c|c|c|}
\hline No & \multicolumn{1}{|c|}{ Model Regression } & $\mathrm{N}$ & Asymp. Sig \\
\hline 1 & $\mathrm{Y}=\alpha+\beta_{1} \mathrm{X}_{1}+\beta_{2} \mathrm{X}_{2}+\mathrm{e}$ & 40 & 0,122 \\
\hline 2 & $\mathrm{Y}=\alpha+\beta_{1} \mathrm{X}_{1}+\beta_{2} \mathrm{X}_{2}+\beta_{3} \mathrm{X}_{3}+\beta_{4} \mathrm{X}_{1} \mathrm{X}_{3}+\beta_{5} \mathrm{X}_{2} \mathrm{X}_{3}+\mathrm{e}$ & 40 & 0,200 \\
\hline
\end{tabular}

Source: data analysis by using SPSS (2018)

Pada uji normalitas hasilnya menunjukkan nilai koefisien asymp.sig (2-tailed) pada persamaan regresi linear berganda dan MRA masing-masing sebesar 0,122 dan 0,200 lebih besar dari nilai signifikansi 0,05 yang berarti kedua model persamaan berdistribusi normal.

Tabel 3 - Uji Multikolinearitas

\begin{tabular}{|c|c|c|c|}
\hline Persamaan & Variabel & Tolerance & VIF \\
\hline $\mathrm{Y}=\alpha+\beta_{1} \mathrm{X}_{1}+\beta_{2} \mathrm{X}_{2}+\mathrm{e}$ & $\mathrm{X}_{1}$ & 0,830 & 1,205 \\
\cline { 2 - 4 } $\mathrm{Y}=\alpha+\beta_{1} \mathrm{X}_{1}+\beta_{2} \mathrm{X}_{2}+\beta_{3} \mathrm{X}_{3}+\beta_{4} \mathrm{X}_{1} \mathrm{X}_{3}+\beta_{5} \mathrm{X}_{2} \mathrm{X}_{3}+\mathrm{e}$ & $\mathrm{X}_{2}$ & 0,830 & 1,205 \\
\cline { 2 - 4 } & $\mathrm{X}_{2}$ & 0,174 & 5,101 \\
\cline { 2 - 4 } & $\mathrm{X}_{3}$ & 0,278 & 3,603 \\
\cline { 2 - 4 } & $\mathrm{X}_{1} \mathrm{X}_{3}$ & 0,118 & 8,460 \\
\cline { 2 - 4 } & $\mathrm{X}_{2} \mathrm{X}_{3}$ & 0,124 & 8,096 \\
\hline
\end{tabular}

Source: data analysis by using SPSS (2018)

Pada uji multikolinearitas ditemukan nilai tolerance masing-masing variabel pada kedua model persamaan lebih besar dari $10 \%$ atau 0,10 dan nilai VIF (Variance Inflation Factor) tiap variabel kurang dari 10, hasil tersebut menunjukkan bahwa tidak terdapat multikolinearitas pada variabel penelitian.

Tabel 4 - Uji Heteroskedastisitas

\begin{tabular}{|c|c|c|}
\hline Persamaan & Variabel & Signifikansi \\
\hline $\mathrm{Y}=\alpha+\beta_{1} \mathrm{X}_{1}+\beta_{2} \mathrm{X}_{2}+\mathrm{e}$ & $\mathrm{X}_{1}$ & 0,842 \\
\cline { 2 - 3 } & $\mathrm{X}_{2}$ & 0,613 \\
\hline $\mathrm{Y}=\alpha+\beta_{1} \mathrm{X}_{1}+\beta_{2} \mathrm{X}_{2}+\beta_{3} \mathrm{X}_{3}+\beta_{4} \mathrm{X}_{1} \mathrm{X}_{3}+\beta_{5} \mathrm{X}_{2} \mathrm{X}_{3}+\mathrm{e}$ & $\mathrm{X}_{1}$ & 0,526 \\
\hline
\end{tabular}




\begin{tabular}{|c|c|}
\hline $\mathrm{X}_{2}$ & 0,500 \\
\hline $\mathrm{X}_{3}$ & 0,587 \\
\hline $\mathrm{X}_{1} \mathrm{X}_{3}$ & 0,552 \\
\hline $\mathrm{X}_{2} \mathrm{X}_{3}$ & 0,274 \\
\hline
\end{tabular}

Source: data analysis by using SPSS (2018)

Pada hasil uji heteroskedastisitas ditemukan bahwa nilai signifikansi masing-masing variabel pada kedua model persamaan regresi lebih besar dari 0,05 sehingga dapat disimpulkan bahwa model regresi dalam penelitian ini bebas dari gejala heteroskedastisitas.

Analisis statistik regresi linear berganda digunakan untuk menguji pengaruh equity sensitivity dan ethical sensitivity pada perilaku etis auditor BPK dan analisis MRA (Moderated Regression Analysis) digunakan untuk menguji bagaimana filosofi tri kaya parisudha memoderasi pengaruh equity sensitivity dan ethical sensitivity pada perilaku etis auditor BPK Perwakilan Provinsi Bali. Hasil uji regresi linear berganda dan MRA ditunjukkan sebagai berikut:

Tabel 5 - Uji Regresi Linear Berganda

\begin{tabular}{|c|c|c|c|c|c|}
\hline \multirow[t]{2}{*}{ Model } & \multicolumn{2}{|c|}{$\begin{array}{c}\text { Unstandardized } \\
\text { Coeficients }\end{array}$} & \multirow{2}{*}{$\begin{array}{c}\begin{array}{c}\text { Standardized } \\
\text { Coeficients }\end{array} \\
\text { Beta }\end{array}$} & \multirow[b]{2}{*}{$t$} & \multirow[b]{2}{*}{ Sig. } \\
\hline & $B$ & $\begin{array}{c}\text { Std. } \\
\text { Error }\end{array}$ & & & \\
\hline (Constant) & $-0,464$ & 3,123 & - & $-1,48$ & 0,883 \\
\hline Equity Sensitivity $\left(X_{1}\right)$ & 0,460 & 0,089 & 0,493 & 5,173 & 0,000 \\
\hline Ethical Sensitivity $\left(X_{2}\right)$ & 1,411 & 0,260 & 0,517 & 5,427 & 0,000 \\
\hline$R$ & & & 0,849 & & \\
\hline$R^{2}$ & & & 0,721 & & \\
\hline Adjusted $\left(R^{2}\right)$ & & & 0,706 & & \\
\hline F Hitung & & & 47,791 & & \\
\hline Signifikansi $F$ & & & 0,000 & & \\
\hline
\end{tabular}

Source: data analysis by using SPSS (2018)

Berdasarkan Tabel 5 maka dapat disusun persamaan regresi sebagai berikut:

$\mathrm{Y}=\alpha+\beta_{1} \mathrm{X}_{1}+\beta_{2} \mathrm{X}_{2}+\mathrm{e}$

$\mathrm{Y}=-0,464+0,460 \mathrm{X}_{1}+1,411 \mathrm{X}_{2+} \mathrm{e}$

Persamaan regresi menunjukkan bahwa variabel equity sensitivity dan ethical sensitivity memiliki nilai koefisien positif. Jika variabel equity sensitivity dan ethical sensitivity bernilai nol, maka variabel perilaku etis juga bernilai nol yang berarti jika auditor tidak memiliki equity sensitivity

dan ethical sensitivity maka auditor tersebut tidak memiliki perilaku etis maupun perilaku tidak etis. Nilai adjusted $\left(\mathrm{R}^{2}\right)$ sebesar 0,706 yang berarti bahwa $70,6 \%$ variasi variabel terikat perilaku etis auditor mampu dijelaskan oleh variasi variabel equity sensitivity dan ethical sensitivity. Sisanya 
sebesar 29,4\% dipengaruhi oleh variabel lain yang tidak termasuk ke dalam model penelitian. Nilai $\mathrm{F}$ hitung ditemukan sebesar 47,791 dengan tingkat signifikansi 0,000 lebih kecil dari alpha 0,05 yang menunjukkan model yang digunakan dalam penelitian ini adalah layak. Pada hasil uji signifikansi parsial (uji t) ditemukan variabel equity sensitivity memiliki $\mathrm{t}$ hitung positif 5,173 dan nilai signifikansi sebesar 0,000 kurang dari 0,05. Hal ini berarti equity sensitivity berpengaruh positif signifikan pada perilaku etis auditor, sehingga hipotesis 1 diterima dan hipotesis 0 ditolak. Pada variabel ethical sensitivity ditemukan nilai $\mathrm{t}$ hitung positif sebesar 5,427 dengan tingkat signifikansi 0,000 kurang dari 0,05 . Hal ini berarti ethical sensitivity berpengaruh positif signifikan pada perilaku etis auditor, sehingga hipotesis 2 diterima dan hipotesis 0 ditolak.

Tabel 6 - Uji MRA (Moderated Regression Analysis)

\begin{tabular}{|c|c|c|c|c|c|}
\hline \multirow[t]{2}{*}{ Model } & \multicolumn{2}{|c|}{$\begin{array}{c}\text { Unstandardized } \\
\text { Coeficients }\end{array}$} & \multirow{2}{*}{\begin{tabular}{|c|}
$\begin{array}{c}\text { Standardized } \\
\text { Coeficients }\end{array}$ \\
Beta \\
\end{tabular}} & \multirow[b]{2}{*}{$\mathbf{t}$} & \multirow[b]{2}{*}{ Sig. } \\
\hline & B & $\begin{array}{l}\text { Std. } \\
\text { Error }\end{array}$ & & & \\
\hline (Constant) & $-94,439$ & 36,984 & - & $-2,554$ & 0,015 \\
\hline Equity Sensitivity $\left(\mathrm{X}_{1}\right)$ & $-0,533$ & 0,326 & $-0,571$ & $-1,637$ & 0,111 \\
\hline Ethical Sensitivity $\left(\mathrm{X}_{2}\right)$ & $-1,602$ & 0,833 & $-0,588$ & $-1,924$ & 0,063 \\
\hline Tri kaya parisudha $\left(\mathrm{X}_{3}\right)$ & $-1,356$ & 0,369 & $-1,942$ & $-3,675$ & 0,001 \\
\hline $\mathrm{X}_{1} * \mathrm{X}_{3}$ & 25,250 & 8,340 & 1,763 & 3,028 & 0,005 \\
\hline $\mathrm{X}_{2} * \mathrm{X}_{3}$ & 0,074 & 0,019 & 2,070 & 3.890 & 0,000 \\
\hline $\mathrm{R}$ & & & 0,901 & & \\
\hline $\mathrm{R}^{2}$ & & & 0,813 & & \\
\hline Adjusted $\left(\mathrm{R}^{2}\right)$ & & & 0,785 & & \\
\hline F Hitung & & & 29,498 & & \\
\hline Signifikansi F & & & 0,000 & & \\
\hline
\end{tabular}

Source: data analysis by using SPSS (2018)

Berdasarkan tabel 6 dapat disusun persamaan regresi sebagai berikut:

$Y=\alpha+\beta_{1} X_{1}+\beta_{2} X_{2}+\beta_{3} X_{3}+\beta_{4} X_{1} X_{3}+\beta_{5} X_{2} X_{3}+e$

$Y=-94,439-0,533 X_{1}-1,602 X_{2}-1,356 X_{3}+25,250 X_{1} X_{3}+0,074 X_{2} X_{3}$

Koefisien moderasi $\left(\beta_{4}\right)$ bernilai positif 25,250 yang berarti jika interaksi antara equity sensitivity dan tri kaya parisudha meningkat satu satuan maka equity sensitivity disertai pemahaman filosofi tri kaya parisudha akan menguatkan pengaruh equity sensitivity pada perilaku etis auditor sebesar 25,250. Koefisien moderasi $\left(\beta_{5}\right)$ sebesar 0,074 bernilai positif yang berarti jika interaksi antara ethical sensitivity dan tri kaya parisudha meningkat satu satuan maka ethical sensitivity disertai pemahaman filosofi tri kaya parisudha akan menguatkan pengaruh ethical sensitivity pada perilaku etis auditor sebesar 0,074. Berdasarkan Tabel 6 , nilai adjusted $\left(\mathrm{R}^{2}\right)$ sebesar 0,785 berarti bahwa sebesar $78,5 \%$ variabel terikat perilaku etis dapat dijelaskan oleh variabel 
equity sensitivity dan ethical sensitivity yang dimoderasi oleh tri kaya parisudha, sedangkan sisanya $21,5 \%$ dipengaruhi variabel lain yang tidak termasuk dalam model penelitian. Hasil analisis uji $F$ menunjukkan tingkat signifikansi 0,000 lebih kecil dari $\alpha(0,05)$ yang berarti model penelitian ini layak digunakan untuk pembuktian atas hipotesis yang dibentuk. Hasil uji signifikansi parsial (uji t) menunjukkan interaksi tri kaya parisudha dan equity sensitivity memiliki nilai t hitung sebesar 3,028 dengan nilai signifikansi 0,005 yang berarti $\mathrm{H}_{3}$ diterima dan $\mathrm{H}_{0}$ ditolak. Hal ini menunjukkan filosofi tri kaya parisudha mampu memoderasi pengaruh equity sensitivity pada perilaku etis auditor. Hasil interaksi tri kaya parisudha dan ethical sensitivity memiliki nilai $\mathrm{t}$ hitung 3,890 dengan nilai signifikansi sebesar 0,000 yang berarti $\mathrm{H}_{4}$ diterima dan $\mathrm{H}_{0}$ ditolak. Ini menunjukkan filosofi tri kaya parisudha mampu memoderasi pengaruh ethical sensitivity pada perilaku etis auditor.

Hasil dari analisis regresi linear berganda dan uji MRA menunjukkan bahwa empat hipotesis yang dibangun di dalam penelitian ini semuanya diterima. Variabel equity sensitivity memiliki koefisien regresi sebesar 0,460 dan nilai siginifikansi 0,000 (< $0,05)$ yang berarti hipotesis $1\left(\mathrm{H}_{1}\right)$ diterima. Ini menunjukkan equity sensitivity berpengaruh positif signifikan pada perilaku etis auditor BPK Perwakilan Provinsi Bali. Koefisein regresi bernilai positif berarti semakin tinggi equity sensitivity yang dimiliki auditor maka semakin meningkat pula perilaku etis yang ditunjukkan. Auditor yang berada pada titik keseimbangan antara input dan outcomes maka kecenderungannya berperilaku etis lebih tinggi dibandingkan auditor yang tidak memiliki equity sensitivity. Rasa syukur yang dimiliki tiap individu dalam hidup juga dapat membentuk persepsi keadilan dan titik keseimbangan yang dimiliki sehingga mempengaruhi perilakunya. Hasil penelitian ini sejalan dengan teori atribusi yang menjelaskan tentang perilaku individu dimana teori ini menyatakan proses penyebab dan motif perilaku seseorang. Hal ini juga sejalan dengan teori etika dimana Pojman (1989) menyatakan bahwa perbedaan benar salah, baik buruk, adil dan tidak adil dapat dijelaskan dalam konsep moral. Semakin meningkat pemahaman individu terhadap konsep moral adil dan tidak adil, maka semakin meningkat pula kecenderungan individu berperilaku etis.

Uji hipotesis kedua menunjukkan variabel ethical sensitivity memiliki koefisien regresi sebesar 1,411 dan nilai signifikan $0,000 \quad(<0,05)$ yang berarti hipotesis $2 \quad\left(\mathrm{H}_{2}\right)$ diterima. Hal ini membuktikan ethical sensitivity berpengaruh positif signifikan pada perilaku etis auditor. Koefisien regresi bernilai positif berarti semakin tinggi ethical sensitivity yang dimiliki auditor maka akan semakin tinggi perilaku etis yang ditunjukkan auditor dalam menjalankan tugasnya. Auditor yang memiliki kemampuan mengenali kehadiran nilai-nilai etika, akan menggunakan nilainilai tersebut sebagai landasan moral yang menuntunnya dalam berperilaku lebih etis. Hasil penelitian sejalan dengan teori atribusi yang menjelaskan bahwa kemampuan individu merupakan salah satu faktor internal yang mempengaruhi perilakunya. Teori etika juga sejalan dengan hasil penelitian dimana etika terdiri dari prinsip-prinsip moral dan standar yang mendorong individu berperilaku etis. Semakin tinggi kemampuan individu memahami nilai moral dan etika, maka semakin tinggi pula kemampuannya berperilaku etis.

Pada pengujian hipotesis ketiga, variabel moderasi tri kaya parisudha memiliki koefisien regresi sebesar 25,250 dan nilai signifikansi $0,005(<0,05)$ yang berarti hipotesis $3\left(\mathrm{H}_{3}\right)$ diterima. Hal ini membuktikan bahwa filosofi tri kaya parisudha memperkuat pengaruh equity sensitivity pada perilaku etis auditor BPK Perwakilan Provinsi Bali. Koefisien regresi bernilai positif berarti semakin meningkat equity sensitivity yang disertai pemahaman filosofi tri kaya parisudha maka akan menguatkan pengaruh equity sensitivity pada perilaku etis auditor. Hasil penelitian sejalan 
dengan teori atribusi yang menjelaskan bahwa perilaku individu selain dipengaruhi oleh faktor internal, juga dipengaruhi oleh faktor eksternal seperti lingkungan, tekanan situasi atau keadaan tertentu. Luthans (2005) menjelaskan bahwa lingkungan seperti kondisi sosial, nilai-nilai sosial, dan pandangan masyarakat merupakan penyebab eksternal yang dapat mempengaruhi perilaku seseorang. Hasil penelitian juga sejalan dengan teori perkembangan moral kognitif dari Kohlberg yang menyatakan individu dapat mempersepsi lingkungannya dalam tahapan-tahapan perkembangan. Teori ini berpendapat bahwa seorang auditor dapat membangun kemampuan kognitif melalui tindakan yang termotivasi terhadap lingkungan. Kesadaran dan persepsi manusia akan keadilan dan prinsip-prinsip etis tidak terlepas dari ajaran agama seperti di dalam ajaran tri kaya parisudha yang merupakan faktor eksternal yang mengajarkan nilai-nilai etika untuk menuntun individu berperilaku etis.

Hasil pengujian pada hipotesis keempat menunjukkan variabel moderasi tri kaya parisudha memiliki nilai koefisien regresi sebesar 0,074 dan nilai signifikansi sebesar $0,000(<0,05)$ yang berarti hipotesis $4\left(\mathrm{H}_{4}\right)$ diterima. Hal ini membuktikan bahwa filosofi tri kaya parisudha memperkuat pengaruh ethical sensitivity pada perilaku etis auditor. Koefisien regresi yang bernilai positif berarti semakin tinggi penerapan ethical sensitivity disertai dengan filosofi tri kaya parisudha yang dilakukan oleh auditor maka semakin tinggi pengaruh ethical sensitivity pada perilaku etis auditor. Hasil penelitian sejalan dengan teori atribusi yang menyatakan kemampuan individu memahami nilai etika dipengaruhi faktor eksternal seperti ajaran agama. Tri kaya parisudha adalah salah satu ajaran susila atau etika dalam agama Hindu yang mempengaruhi kemampuan individu memahami nilai moral dan etika sebagai tuntunan berperilaku. Sejalan juga dengan teori perkembangan moral kognitif yang menyatakan penalaran moral dipandang sebagai suatu struktur bukan isi. Jika penalaran moral dipandang sebagai isi, maka sesuatu dikatakan baik atau buruk akan sangat tergantung pada lingkungan sosial budaya tertentu sehingga sifatnya akan relatif. Tetapi jika penalaran moral dilihat sebagai struktur, maka apa yang baik dan buruk terkait dengan prinsip moralitas, sehingga penalaran moral bersifat universal.

\section{KESIMPULAN}

Berdasarkan hasil analisis dan pembahasan maka dapat ditarik kesimpulan sebagai berikut:

1. Equity sensitivity berpengaruh positif pada perilaku etis auditor BPK Perwakilan Provinsi Bali. Semakin tinggi equity sensitivity yang dimiliki oleh auditor maka akan semakin tinggi perilaku etis yang dimiliki oleh auditor BPK Perwakilan Provinsi Bali baik dalam pengambilan keputusan maupun menjalankan tugas professional.

2. Ethical sensitivity berpengaruh positif pada perilaku etis auditor BPK Perwakilan Provinsi Bali. Semakin tinggi ethical sensitivity atau kemampuan auditor memahami konten etis maka akan semakin tinggi perilaku etis yang dimiliki oleh auditor.

3. Filosofi tri kaya parisudha mampu memperkuat pengaruh equity sensitivity pada perilaku etis auditor BPK Perwakilan Provinsi Bali. Equity sensitivity yang disertai pemahaman filosofi tri kaya parisudha menguatkan pengaruh equity sensitivity pada perilaku etis auditor.

4. Filosofi tri kaya parisudha mampu memperkuat pengaruh ethical sensitivity pada perilaku etis auditor BPK Perwakilan Provinsi Bali. Ethical sensitivity yang disertai pemahaman filosofi tri kaya parisudha menguatkan pengaruh ethical sensitivity pada perilaku etis auditor. 
DAFTAR PUSTAKA

Alteer, Mohammad Ahmed., Yahya, Sofri., Haron, Harashid. (2013). Religiosity and Auditors Ethical Sensitivity at Different Levels of Ethical Climate: A Conceptual Link. American Journal of Economics 2013, 3 (5C): 119-124.

Alleyne, Phillmore., McClean, Cheryl. Cadogan. (2013). Examining Personal Values and Ethical Behavior Perceptions between Accounting and Non Accounting Students in the Caribbean University of the West Indies. The Accounting Educator's Journal. Volume XXIII 2013.

Akaah, I.P., Lund, D. (1994). The Influence of Personal and Organizational Values on Marketing Professional Ethical Behavior. Journal of Business Ethics. 13:417-430.

BPK RI. www.bpk.go.id (diakses pada tanggal 1 Desember 2017).

Dewi, Purnama. (2015). Pengaruh Pengalaman, Orientasi Etika, Komitmen dan Budaya Etis Organisasi Pada Sensitivitas Etika Auditor Badan Pengawasan Keuangan dan Pembangunan Provinsi Bali. Tesis. Pasca Sarjana Akuntansi Universitas Udayana Denpasar Bali.

Fauzan. (2016). Pengaruh Religiusitas dan Ethical Climate terhadap Ethical Behavior. Universitas Kanjuruhan Malang. ejournal.unikama.ac.id

Fitrah, M. (2018). Urgensi Sistem Penjaminan Mutu Internal Terhadap Peningkatan Mutu Perguruan Tinggi. Jurnal Penjaminan Mutu, 4(1), 76-86.

Heider, Fritz. (1958). The Psychology of Interpersonal Relations. New York: Wiley.

Huseman, R.C., Hatfield, J.D., Miles, E.W. (1987). A New Perspective on Equity
Theory: The Equity Sensitivity Construct. Academy of Management Review. Vol 12: 222-234.

Kohlberg, L. (1977). The Cognitive Development Approach to Moral Education. Issues in Adolescent Psychology: 283-299. New Jersey: Printice Hall Inc.

Kajeng, I Nyoman. (1997). Sarasamuccaya. Paramita. Surabaya.

Luthans, Fred. 2005. Organizational Behavior. Seventh Edition.McGrawHill,Inc.,New York.

Pojman, Louis.P. (1989). Ethical Theory: Classical and Contemporary Readings. Wadsworth Publishing Company. Belmont.

Suardhika, Sadha. I Made. (2015). Mengenal Siapa Aku dalam Membangun atau Mengembangkan Ilmu Pengetahuan (Akuntansi). Fakultas Ekonomi Universitas Udayana. Jurnal Ilmiah Akuntansi dan Bisnis. Vol.10. No 2, Juli 2015.

Shaub, M.K., Don, W. Finn., Munter, Paul. (1993). The Effects of Auditor's Ethical Orientation on Commitement and Ethical Sensitivity. Behavioral Research in Accounting. Vol 5, pp. 145-169.

Sugiyono. (2012). Metode Penelitian Bisnis. Alfabeta. Cetakan ke 16. Bandung.

Sura, I Gede. (2001). Pengendalian Diri dan Etika dalam Ajaran Agama Hindu. Denpasar. Hanuman Sakti.

Sihwahjoeni., Gudono, M. (2000). Persepsi Akuntan terhadap Kode Etik Akuntan. Jurnal Riset Akuntansi Indonesia. Vol.3 (2) Juli: 168-184.

Utama, Suyana. (2016). Aplikasi Analisis Kuantitatif. Fakultas Ekonomi dan Bisnis Universitas Udayana. Denpasar. 